\title{
Energy and rice quality aspects during drying of freshly harvested paddy with industrial inclined bed dryer
}

\begin{abstract}
The performance evaluation of any industrial dryer regarding energy consumption and product quality should be assessed to check its present status and to suggest for further efficient operation. An investigation was carried out to evaluate the impact of drying temperature and air flow on energy consumption and quality of rice during paddy drying with industrial inclined bed dryer (IBD) with average holding capacity of 15 ton in the selected complexes of Padiberas Nasional Berhad (BERNAS)-the national paddy custodian of Malaysia. In reducing paddy moisture content (mc) from $22 \%$ to $23 \%$ wet basis (wb) down to around $12.5 \% \mathrm{wb}$, the final $\mathrm{mc}$, the specific electrical (in terms of primary energy) and the specific thermal energy consumption were found to be varied between 1.44 to $1.95 \mathrm{MJ} / \mathrm{kg}$ water evaporated and 2.77 to $3.47 \mathrm{MJ} / \mathrm{kg}$ water evaporated, respectively. Analysis revealed that the specific electrical energy consumption was around $20 \%$ lesser and the specific thermal energy consumption of IBDs was around $10 \%$ higher during drying with air temperature of $41-42{ }^{\circ} \mathrm{C}$ than drying with $38-39{ }^{\circ} \mathrm{C}$ in reducing paddy mc from $22 \%$ to $23 \%$ (wb) down to around $12.5 \%$ (wb). However, paddy being with almost same initial mc dried using drying temperature of $38-39{ }^{\circ} \mathrm{C}$, IBDs yielded $1-4 \%$ higher head rice yield while milling recovery and whiteness were comparable at acceptable milling degree and transparency. The bed air flows between 0.27 and $0.29 \mathrm{~m} 3 \mathrm{~m}-2 \mathrm{~s}-1$ resulted in higher head rice yield slightly while its effect on drying time was not prominent so much. For paddy with initial moisture content below $23 \% \mathrm{wb}$, it is recommended that drying air temperature should not be higher than $39{ }^{\circ} \mathrm{C}$ in order to maintain rice quality at reasonable energy consumption.
\end{abstract}

Keyword: Industrial paddy drying; Inclined bed dryer; Freshly harvested paddy; Specific energy consumption; Rice quality 